\title{
Biomarkers of Oxidative Stress and Heavy Metal Levels as Indicators of Environmental Pollution in African Cat Fish (Clarias gariepinus) from Nigeria Ogun River
}

\author{
E. O. Farombi*, O. A. Adelowo, and Y. R. Ajimoko \\ Drug Metabolism and Toxicology Research Laboratories, Department of Biochemistry, College of Medicine, University of \\ Ibadan, Nigeria \\ *Correspondence to Dr. E. Olatunde Farombi; Email: olatunde_farombi@yahoo.com
}

Received: 10 January 2007 / Accepted: 15 June 2007 / Published: 30 June 2007

\begin{abstract}
Levels of $\mathrm{Zn}, \mathrm{Cu}, \mathrm{Cd}, \mathrm{As}$, and $\mathrm{Pb}$ in the kidney, Liver, Gills and Heart of African cat fish (Clarias gariepinus) from the Ogun River in Ogun State located close to six major industries in the South Western part of Nigeria, were determined using Bulk Scientific Atomic Absorption Spectrophotometer. Fishes were also collected from Government owned fish farm in Agodi, Ibadan which was considered a reference site. The activities of superoxide dismutase (SOD), catalase (CAT), glutathione S-transferase (GST), glutathione (GSH) concentration and malondialdehyde (MDA) formation were also determined. The trend of accumulation of the metals in the organs is as follows: Heart - $\mathrm{Zn}>\mathrm{Cu}>\mathrm{Pb}>\mathrm{As}>\mathrm{Cd}$; Gills $-\mathrm{Zn}>\mathrm{Cu}>\mathrm{Pb}>\mathrm{Cd}>$ As; Kidney $-\mathrm{Zn}>\mathrm{Cu}>\mathrm{Pb}>\mathrm{As}>$ Cd; Liver $\mathrm{Zn}>\mathrm{Cu}>\mathrm{Pb}>\mathrm{As}>\mathrm{Cd}$. The order of concentration of the metals in the organs is as follows: Arsenite - Kidney $>$ Liver $>$ Gills $>$ Heart; Zinc - Gills $>$ Liver $>$ Kidney $>$ Heart; Lead- Liver $>$ Kidney $>$ Gills $>$ Heart; Copper- Kidney $>$ Liver $>$ Gills $>$ Heart; Cadmium $>$ Liver $>$ Gills $>$ Kidney $>$ Heart. The levels of heavy metals ranged between 0.25$8.96 \mathrm{ppm}$ in the heart, $0.69-19.05 \mathrm{ppm}$ in the kidneys, $2.10-19.75 \mathrm{ppm}$ in the liver and 1.95-20.35 ppm in the gills. SOD activity increased by $61 \%$ in the liver, $50 \%$ in the kidney and in the heart by $28 \%$ while a significant decrease (44\%) was observed in the gill of Clarias gariepinus from Ogun river compared to that Agodi fish farm $(\mathrm{P}<0.001)$. On the contrary there was $46 \%, 41 \%, 50 \%$ and $19 \%$ decrease in CAT activity in the liver, kidney, gills and heart respectively. The levels of GST activities in the liver, kidney and heart of Clarias gariepinus from Ogun river increased by $62 \%, 72 \%$ and $37 \%$ respectively $(\mathrm{P}<0.001)$ whereas there was a significant decrease $(41 \%)$ in the gills $(\mathrm{P}<0.05)$ compared to that from the Agodi fish farm. GSH concentration increased by $81 \%$, $83 \%$ and $53 \%$ in the liver, kidney and heart respectively but decreased by $44 \%$ in the gills. MDA levels of Clarias gariepinus were significantly $(\mathrm{P}<0.001)$ elevated in the liver, kidney, gills and heart by $177 \%, 102 \%, 168 \%$ and $71 \%$ respectively compared to that from Agodi fish farm. Overall, the results demonstrate that alteration in the antioxidant enzymes, glutathione system and induction of lipid peroxidation reflects the presence of heavy metals which may cause oxidative stress in the Clarias gariepinus from Ogun River. The study therefore provides a rational use of biomarkers of oxidative stress in biomonitoring of aquatic pollution.
\end{abstract}

Keywords: Heavy metals, African cat fish, antioxidant enzymes, oxidative stress, biomarkers, environmental pollution

\section{Introduction}

Over the past few decades, heavy metal contamination of aquatic system has attracted the attention of several investigators both in the developed and developing countries of the world. Many industrial and agricultural processes have contributed to the contamination of fresh water systems thereby causing adverse effects on aquatic biota and human health [1, 2].
The fact that heavy metals cannot be destroyed through biological degradation and have the ability to accumulate in the environment make these toxicants deleterious to the aquatic environment and consequently to humans who depend on aquatic products as sources of food. Heavy metals can accumulate in the tissues of aquatic animals and as such tissue concentrations of heavy metals can be of public health concern to both animals and humans $[3,4]$. 
Many Rivers in Nigeria have been reported to be polluted principally due to the discharge of untreated wastes into rivers by many industries [5]. For instance heavy metals like copper, chromium; iron, zinc, cadmium, lead and mercury were found to contaminate the Kaduna River in Nigeria because local textiles, breweries and refineries discharge their untreated waste products into the river [6]. Furthermore Alinnor [6] recently reported that Aba River is polluted due to discharge of wastes from five different industries located close to it. However, Ogun River has received little attention in this respect and no published data exist so far.

Ogun River flows in Ogun state of Nigeria and it is located to two heavily industrialized cities Lagos and Sango-Ota in Nigeria. About six different industries discharge their wastes into the river. The industries include Vitabiotics, Nestle, Glaxos, Smith kline, Sona Breweries and Nigerian German chemicals. People also rear cattle near this river. The river serves as sources of drinking water, fishing and other domestic uses for the population. In view of the enormous discharge of industrial effluents into this river, it becomes imperative to investigate the extent of pollution in the river.

Fish are largely being used for the assessment of the quality of aquatic environment and as such can serve as bioindicators of environmental pollution [2, 7]. Heavy metals accumulated in the tissues of fish may catalyze reactions that generate reactive oxygen species (ROS) which may lead to environmental oxidative stress. Defensive mechanisms to counteract the impact of ROS are found in many mammalian species including aquatic animals such as fish. These systems include various antioxidant defense enzymes such as superoxide dismutases which catalyze the dismutation of superoxide radical to hydrogen peroxide, catalase acting on hydrogen peroxide, glutathione S-transferase family possessing detoxifying activities towards lipid hydroperoxides generated by organic pollutants such as heavy metals [8].

African catfish (Clarias gariepinus) is of great commercial importance because it is the most common fresh water fish widely consumed in Nigeria [9]. It can therefore be a good model to study responses to various environmental contaminants. We therefore report for the first time the levels of $\mathrm{Zn}, \mathrm{Cu}, \mathrm{Cd}, \mathrm{As}$ and $\mathrm{Pb}$ in the kidney, liver, gills and heart of Clarias gariepinus and aquatic environmental stress using antioxidant enzyme system and malondialdehyde formation as surrogate biomarkers of aquatic pollution in Nigeria Ogun River African cat fish.

\section{Materials and methods}

Fish

Clarias gariepinus were caught from Ogun River and transported to the laboratory in ice-cold containers $\left(0-4^{\circ} \mathrm{C}\right)$ on the same day. The fish samples were kept alive for at least 24hrs to minimize stress. Control fishes were collected from Government owned fish farm in Agodi,
Ibadan, Nigeria. According to our knowledge, the fish farm is devoid of any industrial or any other facilities that could cause pollution and thus affect the biochemical responses of the control fish. The fish samples (20) weighed between 470 - 570g. The fishes were dissected and the liver, heart, gills and kidney were quickly removed and the post - mitochondria fraction was prepared as follows: The organs were washed in ice-cold 1.15\%, KCl solution blotted and weighed. They were then homogenized in 4 volumes of homogenizing buffer (50 $\mathrm{mM}$ Tris - $\mathrm{HCl}$ mixed with $1.15 \% \mathrm{KCl}$ and $\mathrm{pH}$ adjusted to 7.4), using Teflon Homogenizer. The resulting homogenate was centrifuged at $10,000 \mathrm{~g}$ for $20 \mathrm{~min}$ in a Beckman L5-50B centrifuge at $0-4^{0} \mathrm{C}$. The supernatant was decanted and stored $-20^{\circ} \mathrm{C}$ until analysis.

\section{Determination of heavy metals in the tissues}

The levels of $\mathrm{Cd}, \mathrm{Zn}, \mathrm{Pb}, \mathrm{As}$ and $\mathrm{Cu}$ of the post mitochondria fraction of the tissues (Kidney, liver, gills and heart) were determined with the aid of Bulk Scientific Atomic Absorption Spectrophotometer, AES, 2000 series. An acetylene air mixture was used as the flame. The working standard for each of the metals were aspired into the flame in the order of $0.0 \mathrm{ppm}, 0.8 \mathrm{ppm}$ and $1.6 \mathrm{ppm}$. The values were used to plot a standard curve. The tissues were then aspirated into the flame and the values were obtained by extrapolation from the standard curve.

\section{Total Protein Estimation}

The protein content of the various fractions was estimated by the method of Lowry et al. [10] using bovine serum albumin as standard.

\section{Assay of Glutathione and Glutathione S-transferase}

Glutathione (GSH) was determined in the $10,000 \mathrm{~g}$ supernatant fraction of the liver, kidney, gills and heart homogenates of Clarias gariepinus according to Jollow et al. [11] at $412 \mathrm{~nm}$ using 5,5'-dithio-bis-2-nitrobenzoic acid (DTNB). Glutathione S-transferase (GST) activity was determined by the method of Habig et al. [12] using 1 chloro 2,4 dinitrobenzene as substrate. The reaction mixture $(3 \mathrm{ml})$ contained $1.7 \mathrm{ml}$ of $100 \mathrm{mM}$ phosphate buffer ( $\mathrm{pH}$ 6.5), $0.1 \mathrm{ml}$ of $30 \mathrm{mM}$ CDNB. After preincubating the reaction mixture at $37^{\circ} \mathrm{C}$ for $5 \mathrm{~min}$, the reaction was started by the addition of $0.1 \mathrm{ml}$ diluted sample and the absorbance was followed for 5 min at 340 $\mathrm{nm}$. Reaction mixture without the enzyme was used as blank. The specific activity of glutathione S-transferase is expressed as nmoles of GSH-CDNB conjugate formed $/ \mathrm{min} / \mathrm{mg}$ protein using an extinction coefficient of $9.6 \mathrm{mM}^{-1} \mathrm{~cm}^{-1}$.

\section{Assay of Antioxidant Enzymes}

Superoxide dismutase (SOD) activity was determined by measuring the inhibition of autoxidation of epinephrine 
at $\mathrm{pH} 10.2$ at $30^{\circ} \mathrm{C}$ as described by Magwere et al. [13]. One unit of SOD activity is the amount of SOD necessary to cause $50 \%$ inhibition of epinephrine autooxidation. Activity of catalase (CAT) was determined according to the procedure of Clairborne [14] by following the absorbance of hydrogen peroxide at $240 \mathrm{~nm}, \mathrm{pH} 7.0$ and $25^{\circ} \mathrm{C}$.

\section{Determination of Malondialdehyde (MDA)}

Lipid peroxidation was determined by measuring the thiobarbituric acid reacting substances (TBARS) as described previously [15]. Malondialdehyde (MDA) was quantitated by using $\Sigma=1.56 \times 10^{5} \mathrm{M}^{-1} \mathrm{~cm}^{-1}$ [16].

\section{Statistics}

All variables were tested for normal distribution using the Kolmogorov-Smirnov test $(\mathrm{P}>0.05)$ and for homogeneity of variance among groups using the Levene's test $(P>0.05)$. ANOVA was used to compare the experimental groups. If significant differences were found $(\mathrm{P}<0.05)$, the treatment groups were compared with the control group using student's test. All the statistics were carried out in SAS (The SAS System for windows, v8; SAS Institute Inc., Cary, NC).

\section{Results}

Heavy Metal Levels

Table 1 shows the levels of heavy metals in the liver, kidney, gills and heart of Clarias gariepinus from the Ogun River. Heavy metals were accumulated in the organs of the fish to varying extent. The trend of accumulation of the metals in the organs is as follows: Heart $-\mathrm{Zn}>\mathrm{Cu}>$ $\mathrm{Pb}>\mathrm{As}>\mathrm{Cd}$; Gills - $\mathrm{Zn}>\mathrm{Cu}>\mathrm{Pb}>\mathrm{Cd}>$ As; Kidney $\mathrm{Zn}>\mathrm{Cu}>\mathrm{Pb}>\mathrm{As}>\mathrm{Cd}$; Liver $-\mathrm{Zn}>\mathrm{Cu}>\mathrm{Pb}>\mathrm{As}>\mathrm{Cd}$. The order of concentration of the metals in the organs is as follows: Arsenite -Kidney > Liver $>$ Gills $>$ Heart ; Zinc $\quad$-Gills $>$ Liver $>$ Kidney $>$ Heart ; Lead- Liver $>$ Kidney $>$ Gills $>$ Heart.; Copper- Kidney $>$ Liver $>$ Gills $>$ Heart; Cadmium $>$ Liver $>$ Gills $>$ Kidney $>$ Heart.

Table 1: The levels of heavy metals in the liver, kidney, gills and heart of Clarias gariepinus from the Ogun River (test sample) and Agodi River (control).

\begin{tabular}{|c|c|c|c|c|}
\hline \multirow{2}{*}{ Heavy Metals } & \multicolumn{4}{|c|}{ Organs of fish } \\
\hline & Heart & Gills & Kidney & Liver \\
\hline \multicolumn{5}{|l|}{$\overline{Z n(p p m)}$} \\
\hline Control & $0.3 \pm 0.01$ & $0.40 \pm 0.02$ & $0.80 \pm 0.01$ & $0.9 \pm 0.01$ \\
\hline Test sample & $8.96 \pm 0.90^{*}$ & $20.35 \pm 0.98^{*}$ & $19.05 \pm 2.34^{*}$ & $19.75 \pm 1.87^{*}$ \\
\hline \% Change & 2886 & 4987 & 2281 & 2094 \\
\hline \multicolumn{5}{|l|}{$\overline{P b}(p p m)$} \\
\hline Control & ND & $0.02 \pm 0.01$ & $0.03 \pm 0.01$ & $0.06 \pm 0.02$ \\
\hline Test sample & $1.69 \pm 0.96$ & $2.40 \pm 0.55^{*}$ & $3.35 \pm 0.38^{*}$ & $3.40 \pm 0.72 *$ \\
\hline \% Change & - & 11900 & 11066 & 5566 \\
\hline \multicolumn{5}{|l|}{$\overline{C u(p p m)}$} \\
\hline Control & $0.09 \pm 0.02$ & $0.13 \pm 0.01$ & $0.15 \pm 0.01$ & $0.18 \pm 0.02$ \\
\hline Test sample & $2.19 \pm 0.33^{*}$ & $4.55 \pm 0.54^{*}$ & $5.0 \pm 0.50 *$ & $4.70 \pm 0.60^{*}$ \\
\hline \% Change & 2333 & 3400 & 3233 & 2511 \\
\hline \multicolumn{5}{|l|}{$\overline{C d(p p m)}$} \\
\hline Control & ND & ND & ND & 0.01 \\
\hline Test sample & $0.25 \pm 0.13$ & $2.05 \pm 0.48$ & $0.69 \pm 0.43$ & $2.10 \pm 0.58$ \\
\hline \% Change & - & - & - & 20900* \\
\hline \multicolumn{5}{|l|}{$\overline{A s}(p p m)$} \\
\hline Control & ND & ND & ND & ND \\
\hline Test sample & $1.0 \pm 0.1$ & $1.95 \pm 0.82$ & $2.30 \pm 0.0 .86$ & $2.15 \pm 0.42$ \\
\hline \% Change & - & - & - & - \\
\hline
\end{tabular}

The results are expressed as mean of 10 fishes \pm SD. ${ }^{*}$ Significantly different from control, $\mathrm{p}<0.001 . \mathrm{ND}=$ Not detected. 
The concentrations of $\mathrm{Cd}, \mathrm{Pb}, \mathrm{As}, \mathrm{Cu}$ and $\mathrm{Zn}$ in all the organs (Table 1) were higher than the acceptable limit for consumption by international standards (FAO, UNEP and WHO). The acceptable limits for consumption for the metals are as follows: Lead - 0.29 ppm, Zinc - 5.0 ppm, Arsenite - 0.01 ppm, Copper - 0.5 ppm and Cadmium $0.05 \mathrm{ppm}$ [17-20]. In addition the levels of the metals in the organs of fish from the Ogun River were higher than the control levels (Agodi fish farm) (Table 1).

\section{Antioxidant and Detoxification Enzymes Activities}

The activities of antioxidant enzymes in the various organs of Clarias gariepinus from the Ogun River are presented in Figures 1-3. SOD activities in fish from the Ogun River were found to be significantly $(\mathrm{P}<0.01)$ increased in the liver and kidney but insignificantly $(\mathrm{P}>0.05)$ in the heart of the fish compared to that from the Agodi fish farm. The activity of this enzyme decreased significantly in the gills $(\mathrm{P}<0.001)$. The percentage increase in SOD activities were $61 \%, 50 \%$ and $28 \%$ respectively compared to control (Fig 6). SOD decreased in the gill by $44 \%$ compared to control (Fig 6). While CAT activities were significantly reduced by $46 \%, 41 \%$, and $50 \%$ in the liver, kidney and gills of Clarias gariepinus from the Ogun River respectively and insignificant reduction (19\%) was observed in the heart $(\mathrm{P}>0.05)$. The levels of GST activities in the liver, kidney and heart of Clarias gariepinus from the Ogun River were high compared to that from the Agodi fish farm $(\mathrm{P}<0.001)$ but there was a significant decrease in the gills $(\mathrm{P}<0.05)$. The level increased by $62 \%, 72 \%$ and $37 \%$ respectively in the liver, kidney and heart and decreased significantly $(41 \%)$ in the gills $(\mathrm{P}<0.01)$ of fish from the Ogun River compared to control fishes from the Agodi fish farm (Fig 6).

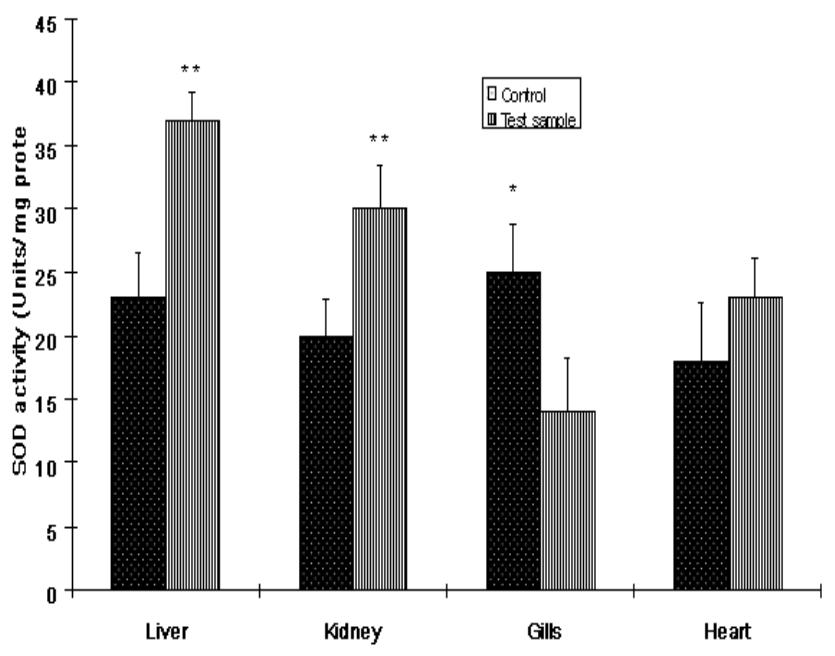

Figure 1: The activities of superoxide dismutase (SOD) in the livers, kidney, Gills and heart of Clarias gariepinus from Ogun River and Agodi farm. Values are mean \pm SD of 10 fishes. Significantly different from control,* $\mathrm{p}<0.001$;** $^{*}<0.01$

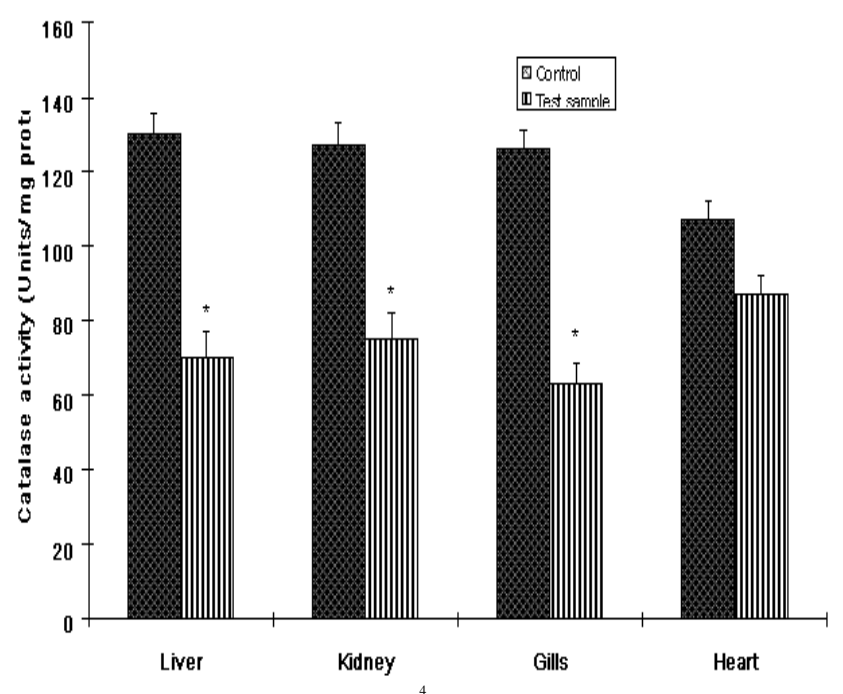

Figure 2: The activities of catalase (CAT) in the livers, kidney, Gills and heart of Clarias gariepinus from Ogun River and Agodi farm. Values are mean \pm SD of 10 fishes. Significantly different from control, ${ }^{*} \mathrm{p}<0.001$

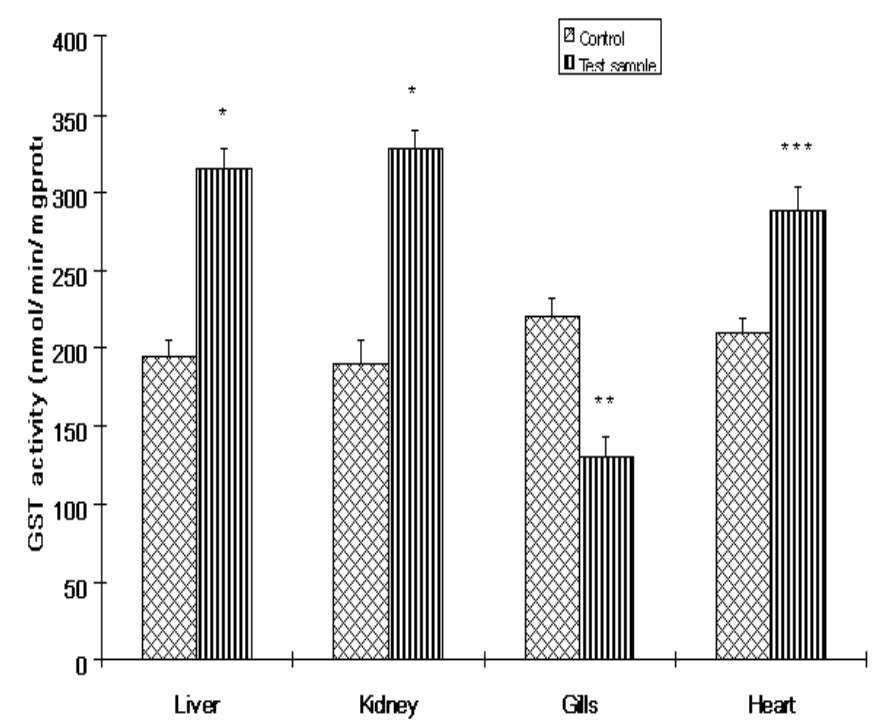

Figure 3: The activities of Glutathione S-transferase (GST) in the livers, kidney, Gills and heart of Clarias gariepinus from the Ogun River and Agodi farm. Values are mean \pm SD of 10 fishes. Significantly different from control, ${ }^{*} \mathrm{p}<0.001 ; * * \mathrm{p}<0.01 ;{ }^{* * *} \mathrm{p}<0.05$

\section{Glutathione Level}

Figure 4 shows the levels of GSH in the various organs of Clarias gariepinus. GSH levels increased significantly in the liver, kidney and heart except the gills of fish from the Ogun River compared to that of control fishes from the Agodi fish farm. The percentage increase in GSH levels were $81 \%$, 83\%, and 53\% respectively for liver, kidney and heart. GSH decreased by $44 \%$ in the gills compared to controls (Fig 6). 


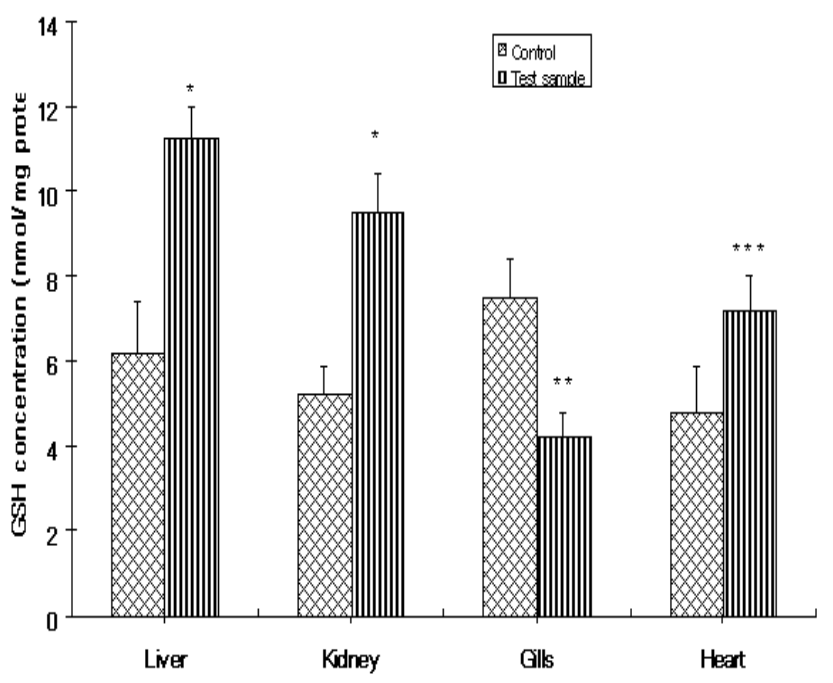

Figure 4: The levels of glutathione (GSH) in the livers, kidney, Gills and heart of Clarias gariepinus from the Ogun River and Agodi farm. Values are mean \pm SD of 10 fishes. Significantly different from control,* $\mathrm{p}<0.001$;** $\mathrm{p}<0.01 ;{ }^{* * *} \mathrm{p}<0.05$.

\section{Lipid Peroxidation}

The levels of MDA formation in Clarias gariepinus are shown in Fig 5. While MDA levels were significantly elevated in all the organs of fishes from the Ogun River compared to that of control fishes from the Agodi fish farm, the level of MDA was markedly increased in the gills $(\mathrm{P}<0.001)$. The percentage increase in lipid peroxidation compared to control for liver, kidney, gills and heart were $177 \%, 102 \%, 168 \%$ and $71 \%$ respectively (Fig 6).

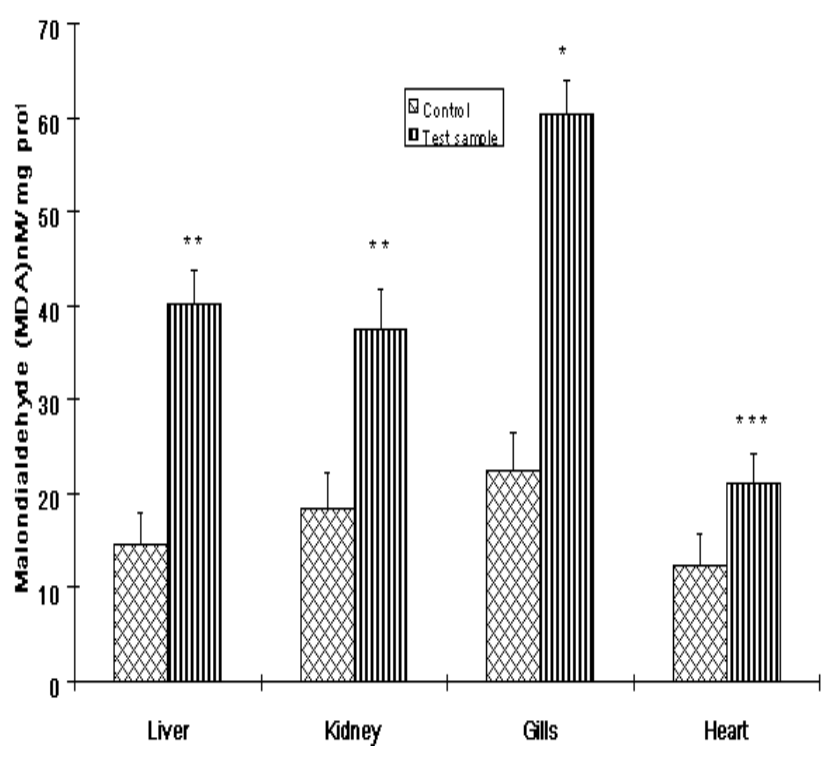

Figure 5: The levels of malondialdehyde (MDA) in the livers, kidney, Gills and heart of Clarias gariepinus from the Ogun River and Agodi farm. Values are mean \pm SD of 10 fishes. Significantly different from control,* $\mathrm{p}<0.001 ; * * \mathrm{p}<0.01 ; * * * \mathrm{p}<0.05$.

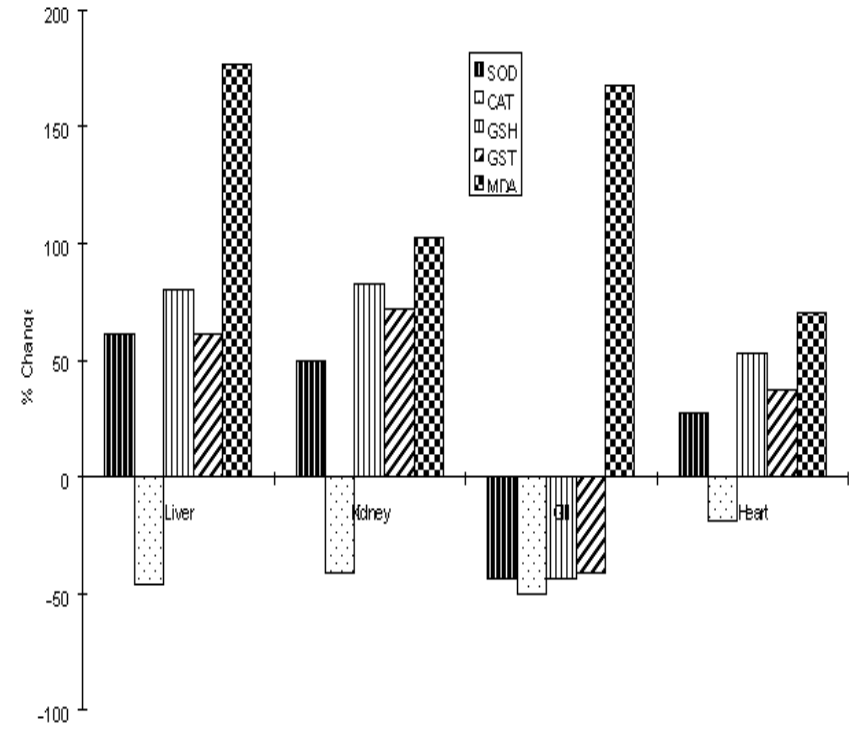

Figure 6: The percentage change in the activities of superoxide dismutase (SOD), catalase (CAT), glutathione S-transferase (GST) and the levels of glutathione (GSH) and malondialdehyde (MDA) in the livers, kidney, Gills and heart of Clarias gariepinus from the Ogun River relative to Agodi farm.

\section{Discussion}

Domestic sewage, combustion emission, mining operations, metallurgical activities and industrial effluents are among the sources of anthropogenic metal inputs and heavy metals such as $\mathrm{Pb}, \mathrm{Cd}, \mathrm{Cu}$ and $\mathrm{Zn}$ are released as a result of these processes [21]. Many Rivers in Nigeria are known to be polluted due to increasing industrial and agricultural production. In the last few decades, attempts have been made regarding the evaluation of aquatic pollution in certain parts of Nigeria [5, 6, 22, 23] but the assessment of metal contamination of fish has been neglected and there are no data regarding the pollution of the Ogun River located close to about six industries that discharge their effluents into the river.

In the present study, we evaluated the levels of heavy metals and certain biomarkers of oxidative stress as surrogate bioindicators of aquatic pollution in Clarias gariepinus which is of commercial importance and widely accepted in Nigeria [9] from the Ogun River. Our data indicate that $\mathrm{Zn}, \mathrm{Cd}, \mathrm{As}, \mathrm{Pb}$ and $\mathrm{Cu}$ were accumulated in high concentrations in the liver, kidney, heart and gills of Clarias gariepinus from the Ogun River which led to induction of lipid peroxidation and alteration in the antioxidant enzymes in the organs of the fish. The concentration of $\mathrm{Zn}$ was high in the gills, liver and kidney of the fish. The highest accumulation of $\mathrm{Zn}$ in the gills may be due to the fact that gills serve as the respiratory organ in fishes through which metal ions are absorbed [24]. The gills are in direct contact with the contaminated medium (water) and have the thinnest epithelium of all the organs and metals can penetrate through the thin epithelia 
cells [24]. Also high level of $\mathrm{Zn}$ in the liver may possibly reflect storage and also due to the fact that the liver being a target and center for metabolism may concentrate heavy metals. The high accumulation of $\mathrm{Zn}$ in the liver and gills observed in our study is in support of the work of Sehgal and Saxena [25] on Clarias gariepinus. Moreover, high concentration of $\mathrm{Zn}$ was recently reported in the liver of seven fish species from the coastal waters of Uruguay [26]. High accumulation of $\mathrm{Zn}$ in the kidney could be based on specific metabolism process and co-enzyme catalyzed reactions involving $\mathrm{Zn}$ taking place in the kidney as reported by Jaffar and Pervaiz [27]. Zn also acts as a catalyst in metal biomolecules bound to amino acid side chains containing $\mathrm{N}, \mathrm{O}$ and (or sulphur legends) (Kendrick et al., 1992, Vinikour et al., 1980) to form tetrahedral zinc metalloproteins and metalloenzymes in kidney tissues [4].

The highest copper concentration in the kidney may be due to the fact that fish kidney contains a cystine rich copper binding protein which is thought to have either a detoxifying or storage function as reported by Luckey and Venugopal [30]. The high concentration of copper in the liver compared to gills and heart can be ascribed to the binding of $\mathrm{Cu}$ to metallothionein in the liver, which serves as a detoxification mechanism. Copper though essential in the diet can be harmful when large intake occurs. The harmful toxicity is largely attributed to its cupric $\left(\mathrm{Cu}^{2+}\right)$ forms which, is the specie commonly found [9].

The concentrations of lead and arsenite in the liver and kidney samples of fish ranged between $2.15 \mathrm{ppm}$ to 3.55 ppm. The two organs contained highest concentrations of these metals compared to other organs. This result shows that both the liver and the kidneys possess the ability to concentrate heavy metals presumably due to the presence of metal binding proteins [31]. Other studies have reported similar concentrations of these metals in the two organs in fish samples [9, 32].

The cadmium concentration reported in our study is consistent and within the range reported in other studies that evaluated metal contamination of fishes. For instance Ashraf reported concentration of $0.41 \mathrm{ppm}$ in the kidney of Epinephelus microdon fish from Arabian Gulf [4]. In another similar study, Kalay et al. [3] reported cadmium level of $1.98 \mathrm{ppm}$ in the liver of Mullus barbatus from the coastal region of Mediterranean Sea. Lower concentration of Cd in kidney has been reported in previous studies [9] and may possibly be due to low tendency of Cd species towards the available active sites ( $\mathrm{N}$ and/or $\mathrm{O}$ donor atoms) in kidney tissues to form tetrahedral or square planer Cd (II) complex species [33]. The mean concentrations in all the organs of the fish were higher than the permissible levels for consumption by International action limit for metals [16-19] indicating metal contamination of the fish and as such via the food chain, consumers of the fish species may be vulnerable to toxicity of the metals.

Our results indicate a significant elevation of lipid peroxidation in all the organs. The apparent increase in lipid peroxidation may be attributed to the accumulation of the heavy metals in the organs as our data indicate significant concentration of heavy metals in the various organs. Metal catalyzed formation of ROS capable of damaging tissues such as DNA, proteins and lipids is well documented [34, 35].

Furthermore, the activities of SOD, GST and the redox sensitive thiol compound GSH were elevated in all the organs except the gills. The significant increase in these organs may be a response to oxidative stress caused by the presence of heavy metals. The accumulation of heavy metals might have led to the production of superoxide anions which led to the induction of SOD to convert the superoxide radical to $\mathrm{H}_{2} \mathrm{O}_{2}$. SOD catalytically scavenges superoxide radical which appears to be an important agent of toxicity of oxygen and this provides a defense against this aspect of oxygen toxicity [36]. GSH is known to be a substrate for the activity of GST. The apparent increase in GSH levels with concomitant elevation in the activity of GST in the organs suggests an adaptive and protective role of this biomolecule against oxidative stress induced by the heavy metals. Our results are in agreement with the findings of Pandey et al. [35] on Wallgo attu fish from the Panipat river in India. The decreased levels of antioxidant enzymes and GSH with lowered level of GST in the gills could account for the marked lipid peroxidation observed. The gills are more exposed to contaminated water and as such metal can penetrate through their thin epithelial cells [23, 37].Under acute oxidative stress, the toxic effects of the pollutants may overwhelm the antioxidant defenses [24]. Furthermore, the apparent decrease in glutathione detoxification system in the gill, the first point of contact with environmental xenobiotics indicates that this system is a sensitive biochemical indicator of environmental pollution [38] in Clarias gariepinus. Increase in the activity of CAT and SOD is usually observed in the face of environmental pollutants [2, 35] since SOD-CAT system represents the first line of defense against oxidative stress [35]. However in the present study, the activity of CAT decreased in all the organs. The decreased CAT activity may be due to the flux of superoxide radicals, which have been shown to inhibit CAT activity [39]. A decrease in the activity of CAT has been previously reported in Cyprinidae fish living in Seyhan dam Lake of Turkey [38] and in sterlet (Acipenser ruthenus L) from the Danube river of Serbia [40].

\section{Conclusion}

Collectively, this study shows that high concentration of $\mathrm{Cd}, \mathrm{Zn}, \mathrm{Pb}, \mathrm{Cu}$ and As accumulated in the liver, kidney, heart and gills of fishes from Ogun River, presumably due to the high level of industrial activities near the river. This could be related to the alterations in antioxidant enzyme activities and other biomarkers of oxidative stress in Clarias gariepinus which may cause biochemical dysfunction in 
this specie. In addition, the results provide evidence that enzymic and non enzymic biomarkers of oxidative stress can be sensitive indicators of aquatic pollution.

\section{References}

1. Wang, W. X.: Interaction of trace metals and different marine food chains. Mar Ecol Prog Ser, 2002, 243, 295-309.

2. Dautremepuits, C.; Paris-Palacios, S.; Betoulle, S.; Vernet, G.: Modulation in hepatic and head kidney parameters of carp (Cyprinus carpio L.) induced by copper and chitosan. Comp Biochem Physiol C Toxicol Pharmacol. 2004, 137, 325-33.

3. Kalay, M.; Ay, P.; Canil, M.: Heavy metal concentration in fish tissues from the northeast Meditereansea. Bull Environ. Contam. Toxicol., 1999, 63, 673-671.

4. Ashraf, W.: Accumulation of heavy metals in kidney and heart tissues of Epinephelus microdon fish from the Arabian Gulf. Environ Monit Assess. 2005, 101, 311.

5. Alinnor, I. J.: Assessment of elemental contaminants in water and fish samples from Aba River. Environ Monit Assess. 2005, 102, 15-25.

6. Oladimeji, A. A.: Impacts of Oil Pollution on Nigerian Fishing Industry. Nigerian Journal of Applied Fisheries and Hydrology. 1987, 2, 81-90.

7. Lopes, P. A.; Pinheiro, T.; Santos, M. C.; da Luz Mathias, M.; Collares-Pereira, M. J.; Viegas-Crespo, A. M.: Response of antioxidant enzymes in freshwater fish populations (Leuciscus alburnoides complex) to inorganic pollutants exposure. Sci Total Environ. 2001, 280, 153-63.

8. Tjalkens, R. B.; Valerio, L. G. Jr.; Awasthi, Y. C.; Petersen, D. R.: Association of glutathione Stransferase isozyme-specific induction and lipid peroxidation in two inbred strains of mice subjected to chronic dietary iron overload. Toxicol Appl Pharmacol. 1998, 151, 174-81.

9. Olaifa, F. G.; Olaifa A. K.; Onwude, T. E.: Lethal and sub lethal effects of copper to the African Cat fish (Clarias gariepinus) African. J. Biomed. Research 2004, 7, 65-70.

10. Lowry, O. H.; Rosenbrough, N. M.; Farr, A. L.; Randall, R. J.; Protein measurement with Folin phenol reagent. J. Biol Chem., 1951, 193, 265.

11. Jollow, D. J.; Michell, J. R.; Zampaglione, N.; Gillete, J. R.: Bromobenzene induced liver Necrosis: Protective role of $\mathrm{GSH}$ and evidence for 3, 4 Bromobenzene oxide as the Hepatotoxic metabolite. Pharmacology, 1974, 11, 151 - 169.

12. Habig, W. H.; Pabst, M. J.; Jacoby, W. B.: Glutathione-S-transferases. The first enzymatic step in mercapturic acid formation. J. Biol. Chem., 1974, 249, 7130-7139.

13. Magwere, T.; Naik, Y. S.; Hasler, J. A.: Effect of chloroquine treatment on antioxidant enzymes in rat liver and kidney. Free Rad. Biol. Med. 1997, 22, 321-327.

14. Clairborne, A.: Catalase activity. In: Handbook of methods for oxygen Radical Research (ed. A.R. Greewald). CRC Press, Florida, 1995, Pp 237-242.

15. Farombi, E. O.; Tahnteng, J. G.; Agboola, O.; Nwankwo, J. O.; Emerole, G. O.: Chemoprevention of 2-acetyl aminofluorene-induced hepatotoxicity and lipid peroxidation in rats by kolaviron- A Garcinia kola seed extract. Food Chem. Toxicol., 2000, 38, 535-541.

16. Buege, J. A.; Aust, S. D.: Microsomal lipid peroxidation. Methods Enzymol. 1978, 52, 302-310.

17. Nauen, C. E.: Compilation of legal limits for hazardous substance in fishes. Circ no 764, FAO, Rome, Italy, 1983.

18. UNEP: Assessment of the present state of pollution by Cadmium, Copper, Zinc and Lead in the Mediterranean Sea. Document UNEP/WG. 144/11 (Athen: UNEP), 1986.

19. WHO: Cadmium. Environmental Health Criteria, (Geneva: WHO) 1992, Vol. 134.

20. WHO: Inorganic lead. Environmental Health Criteria, (Geneva: WHO), 1992, Vol. 165.

21. Chinni, S.; Yallapragda, R.: Toxicity of copper, cadmium, zinc and lead to penaeus indicus postlarvae: Effects of individual metals. J. Environmental Biol. 2000, 21, 255-258.

22. Ibok, U. J.; Udosen, E. D.; Udoidiong, O. M.: Heavy metals in fishes from some streams in Ikot Ekpene area of Nigeria. Nig. J. Tech. Res. 1989, 1, 61-68

23. Nwaedozie, J. M.: The determination of heavy metal pollutants in fish samples from River Kaduna $J$. Chem. Soc. Nigeria. 1998, 23, 21-23

24. Bebianno, M. J.; Geret, F.; Hoarau, P.; Serafim, M. A.; Coelho, M. R.; Gnassia-Barelli, M.; Romeo, M.: Biomarkers in Ruditapes decussatus: a potential bioindicator species. Biomarkers. 2004, 9, 305-30.

25. Sehgal, R.; Saxena, A. B.: Toxicity of zinc to a viviparous fish, Lebistes reticulatus (Peters).Bull Environ Contam Toxicol. 1986, 36, 888-94.

26. Viana, F.; Huertas, R.; Danulat, E: Heavy metal levels in fish from coastal waters of Uruguay. Arch Environ Contam Toxicol. 2005, 48, 530-7.

27. Jaffar, J.; Pervaiz, S.: Investigation of multiorgan heavy metal trace metal content of meat of selected dairy, poultry, fowl and fish species in Pakistan. J. Sci Ind Res. 1989, 32, 175-177.

28. Kendrick, M. H.; Moy, M. T.; Plishka, M. J.; Robinson, K. D.: Metals and biological systems, Ellis Horwood Ltd., Chichester, UK, 1992.

29. Vinikour, W. S.; Goldstein, R. M.; Anderson, R. V.: Bio-concentration patterns of $\mathrm{Zn}, \mathrm{Cu}, \mathrm{Cd}$ and $\mathrm{Pb}$ in selected fish species from the toxic river, Illinois. Bull. Environ. Contam. Toxciol, 1980, 25, 727 - 734.

30. Luckey, T. D.; Venugopal, B.; pT, a new classification system for toxic compounds. J Toxicol Environ Health, 1977, 2, 633-8. 
31. Kargin, F.; Cogun, H. Y.: Metal interactions during accumulation and elimination of Zinc and cadmium in tissues of the fish water fish, Tilapia nilonitica. Bull Environ. Contam. Toxicol., 1999, 63,511 - 519.

32. Babji, A.S.; Embong, M.S.; Woon, W.W: Heavy metal contents in coastal water fishes of West Malaysia. Bull Environ Contam Toxicol. 1979, 23, 830-6.

33. Kappus, H.: Oxidative stress in chemical toxicity. Arch Toxicol. 1987, 60, 144-9.

34. Pandey, S.; Parvez, S.; Sayeed, I.; Haque, R.; BinHafeez, B.; Raisuddin, S.: Biomarkers of oxidative stress: a comparative study of river Yamuna fish Wallago attu (Bl. \& Schn.). Sci Total Environ. 2003, 309, 105-15.

35. McCord, J. M.: Effects of positive iron status at a cellular level. Nutr Rev. 1996, 54, 85-8.
36. Kadar, E.; Costa, V.; Santos, R. S.: Distribution of micro-essential (Fe, Cu, Zn) and toxic (Hg) metals in tissues of two nutritionally distinct hydrothermal shrimps. Sci Total Environ. 2005, 65 - 70.

37. Gul, S.; Belge-Kurutas, E.; Yildiz, E.; Sahan, A.; Doran, F.: Pollution correlated modifications of liver antioxidant systems and histopathology of fish (Cyprinidae) living in Seyhan Dam Lake, Turkey. Environ Int. 2004, 30, 605-9.

38. Kono, Y.; Fridovich, I.: Superoxide radical inhibits catalase. J. Biol. Chem. 1982, 257, 5751-4.

39. Stanic, B.; Andric, N.; Zoric, S.; Grubor-Lajsic, G.; Kovacevic, R.: Assessing pollution in the Danube River near Novi Sad (Serbia) using several biomarkers in sterlet (Acipenser ruthenus L.). Ecotoxicol Environ Safety, 2005, Sep 26. 